\title{
Retromandibular Venous Ectasia Mimicking a Parotid Mass: A Rare Case Report with Computerized Tomography Imaging Findings
}

\author{
Parotis Kitlesini Taklit Eden Retromandibular Venöz Ektazi: Bilgisayarlı Tomografi \\ Görüntüleme Bulguları ile Birlikte Nadir Bir Olgu Sunumu
}

Aslı Tanrıvermiș Sayit, (D) Çetin Çelenk

Ondokuz Mayıs University Faculty of Medicine, Department of Radiology, Samsun, Turkey

\begin{abstract}
Venous ectasia of the retromandibular vein is an extremely rare lesion that may mimic a parotid mass. Patients developing such lesions are often asymptomatic, and the lesions are incidentally detected during imaging tests. Accurate diagnosis is very important to prevent unnecessary surgical procedures. Here we present the case of a patient with venous ectasia of the retromandibular vein that mimicked a parotid mass and was incidentally detected.

Keywords: Retromandibular vein, venous ectasia, computed tomography
\end{abstract}

\section{öz}

Retromandibular venin venöz ektazisi çok nadir olup parotis kitlelerini taklit edebilir. Hastalar sıklıkla asemptomatik olup lezyonlar tesadüfen görüntüleme yöntemleri ile saptanır. Gereksiz cerrahi prosedürlerden kaçınmak için doğru tanı koymak çok önemlidir. Biz burada tesadüfen saptanan ve parotis kitlesini taklit eden retromandibular venöz ektazi olgusunu sunuyoruz.

Anahtar Kelimeler: Retromandibular ven, venöz ektazi, bilgisayarlı tomografi

\section{Introduction}

Venous ectasias of the retromandibular vein (also known as the posterior facial vein) are extremely rare lesions that may mimic a parotid mass on imaging tests (1). Patients are often asymptomatic and incidentally diagnosed through imaging studies performed for other reasons (2). Distinguishing between venous ectasias of the retromandibular vein and parotid masses is crucial to prevent unnecessary invasive investigations or procedures. Doppler ultrasound (US), computed tomography (CT) and magnetic resonance imaging (MRI) can be used for diagnosis. Here, we present the case of a patient with venous ectasia of the retromandibular vein that mimicked a parotid mass and was incidentally detected in a patient aged 59 years.

\section{Case Report}

A 59-year-old female patient, who was operated on for an intracranial lesion in the right frontal region 6 months ago, was admitted to the general internal medicine service for control. Vital signs, laboratory findings and systemic physical examination were normal. There was no palpable mass or lymphadenopathy in the cervical and supraclavicular region. A brain MRI was performed for control. A tubular mass-like lesion was incidentally noted in the left parotid gland. It was hypointense on T1 weighted images (T1WIs) (Figure 1a) and hyperintense on T2 weighted images (T2WIs) (Figure 1b). Moreover, contrast-enhanced T1WIs (Figure 1c) showed marked enhancement. A contrast-enhanced neck CT image revealed a well-defined, lobulated, enhancing left parotid mass on axial images (Figure 2a, b). It appeared to be tubular and inseparable from the
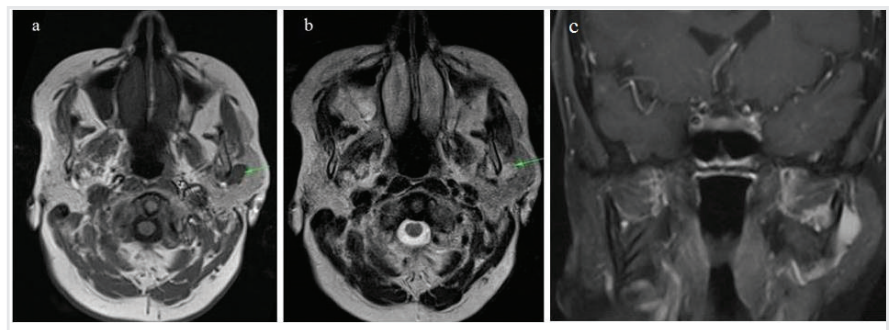

Figure 1a, b, c: A mass-like lesion is seen hypointense on $\mathrm{T} 1$ weighted images (T1WIs) (a) and hyperintense on T2 weighted images (b) within the left parotid gland. Contrast-enhanced T1WI (c) shows a tubular enhanced lesion in the left parotid gland which is considered to be retromandibular vein ectasia
Address for Correspondence/Yazıșma Adresi: Aslı Tanrıvermiş Sayit MD, Ondokuz Mayıs University Faculty of Medicine, Department of Radiology, Samsun, Turkey

Phone: +90 5324949082 E-mail: draslitanrivermissayit@gmail.com 0RCID ID: orcid.org/0000-0003-2861-156X

Cite this article as/Atıf: : Tanrıvermiş Sayit A, Çelenk Ç. Retromandibular Venous Ectasia Mimicking a Parotid Mass: A Rare Case Report with Computerized Tomography Imaging Findings. İstanbul Med J 2020; 21(3): 228-9.
Received/Geliș Tarihi: 03.03.2020 Accepted/Kabul Tarihi: 25.03 .2020

(C) Copyright 2020 by the University of Health Sciences Turkey, Istanbul Training and Research Hospital/istanbul Medical Journal published by Galenos Publishing House.

(c) Telif Hakkı 2020 Sağılk Bilimleri Üniversitesi Istanbul Ĕgitim ve Araştırma Hastanesi/Istanbul Tıp Dergisi, Galenos Yayınevi tarafından basılmıștır. 
retromandibular vein on the coronal (Fig 2c) and sagittal reformatted images (Figure 2d). Venous ectasia of the retromandibular vein was initially considered in the patient; she had no history of neck surgery or infection. Her ears, nose and throat were normal. There was no cervical lymphadenopathy.Consequently, no intervention or follow-up was required for the lesion because it was asymptomatic. An informed verbal consent was provided from the patient.

\section{Discussion}

The retromandibular vein is formed by the union of the superficial temporal and maxillary veins and it descends into the substance of the parotid gland, superficial to the external carotid artery but beneath the facial nerve, between the ramus of the mandible and the sternocleidomastoideus muscle. A commonly encountered variation is when the retromandibular vein crosses the parotid gland. The classification system of the International Society for the Study of Vascular Anomalies splits vascular anomalies into two primary biological categories: vascular neoplasms and malformations (3). Vascular malformations are classified as low-flow malformations (capillaries, veins and lymphatic vessels), high-flow malformations (arterial malformations, arteriovenous malformations and arteriovenous fistula) and combined malformations (phrase and venolymphatic malformation) (3). According to this classification, venous ectasia is considered a low-flow vascular malformation. Venous ectasia is rarely observed in the neck and primarily occurs in the internal and external jugular veins. Its occurrence in the parotid area is very rare, and there are a limited number of case reports in the literature (1).

Similar to aneurysm, venous ectasia is characterised by structural weakening of the vessel wall. Local trauma, inflammation, congenital weakness, localised degenerative changes and possibly elevated vascular flow and pressure are the possible causes of venous ectasia (1). Venous ectasia is of no clinical significance, except for possible cosmetic problems, which may not be present owing to deep localisation.

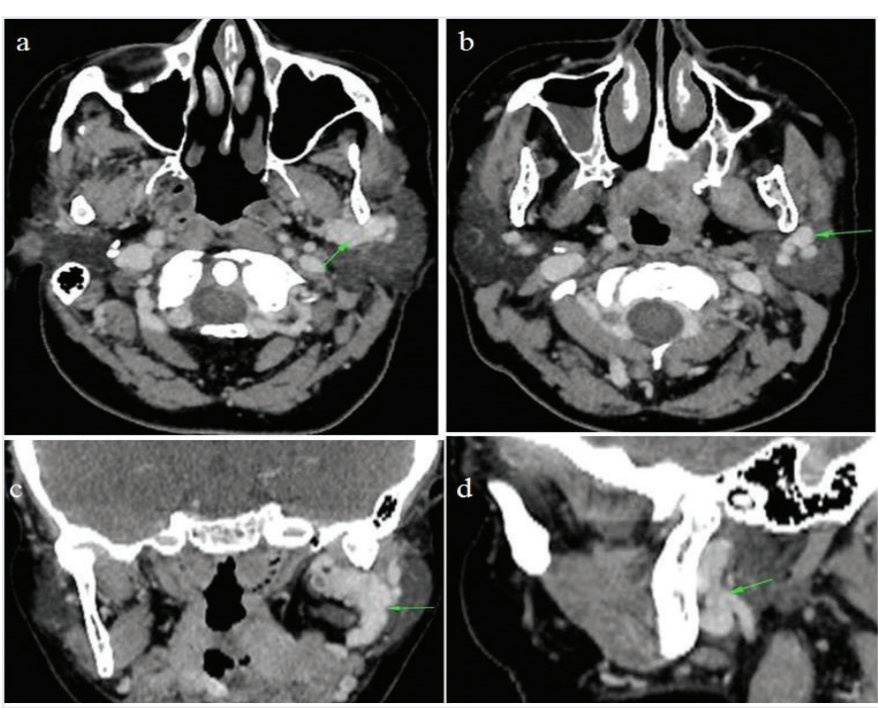

Figure 2a, b, c, d: A contrast-enhanced computed tomography shows a well-defined, lobulated, enhancing left parotid mass (arrow) on axial images (a, b). It also appears tubular and inseparable from the retromandibular vein (arrow) on the coronal (c) and sagittal (d) reformatted images
It is often asymptomatic and rarely causes pulmonary embolism, thrombophlebitis, rupture or thrombosis (2). Pulmonary embolism owing to external jugular vein aneurysm has been reported in the literature; therefore, pulmonary embolism should be considered in cases of large retromandibular venous ectasias (4).

For the diagnosis of venous ectasia, imaging methods, such as Doppler US, CT, MRI and venography, can be used (5). Fusiform or saccular anechoic cystic lesions present with venous flow on colour Doppler US examination. In addition, using the Valsalva maneuver during the Doppler US is very useful for diagnosis. Venous ectasia is noted to be hyperdense on contrast-enhanced CT images, possibly mimicking benign or malignant parotid masses, lymphadenopathies and other venous malformations. Venography is useful in diagnosis (5); however, it is not preferred because it is invasive. It is important to differentiate between venous malformations and parotid masses and to protect the patient from unnecessary invasive procedures and surgery. Therefore, radiologic imaging methods must be used for an accurate diagnosis showing that the lesion originates from the retromandibular vein. Because retromandibular venous ectasia is asymptomatic, treatment is only administered in cases having cosmetic problems. Ligation surgery or partial parotidectomy can be performed (5).

\section{Conclusion}

Venous ectasia of the retromandibular vein is an extremely rare lesion. Using imaging methods, we can differentiate between venous ectasias and benign and malignant parotid masses. Herein, we present a case of retromandibular venous ectasia incidentally diagnosed via CT images.

\section{Ethics}

Informed Consent: An informed verbal consent was provided from the patient.

Peer-review: Internally peer-reviewed.

Authorship Contributions: Surgical and Medical Practices - A.T.S., C..C..; Concept - A.T.S.; Design - A.T.S., C.C..; Data Collection or Processing A.T.S., Ç.Ç.; Analysis or Interpretation - A.T.S., C..C..; Literature Search A.T.S.; Writing - A.T.S., Ç.Ç.

Conflict of Interest: No conflict of interest was declared by the authors.

Financial Disclosure: The authors declared that this study received no financial support.

\section{References}

1. Well DS, Noor A, Berman PD, Som P. Radiological Case: Retromandibular vein ectasia. Appl Radiol 2014.

2. Ilica AT, Senturk S, Kertmen M, Bukte Y, Bilici A, Atasoy MM. Facial vein aneurysm associated with sialadenitis. J Clin Ultrasound 2012; 40: 319-21.

3. Lowe LH, Marchant TC, Rivard DC, Scherbel AJ. Vascular malformations: classification and terminology the radiologist needs to know. Semin Roentgenol 2012; 47: 106-17.

4. Ioannou CV, Kostas T, Tsetis D, Georgakarakos E, Gionis M, Katsamouris AN External jugular vein aneurysm: A source of thrombotic complications. Int Angiol 2010; 29: 284-5.

5. Wali GN, Mawby TAR, Sheerin F, Milford CA. Varix of the retromandibular vein within the parotid gland: case study. J Laryngol Otol 2013; 127: 825-7. 